WellBeing International

WBI Studies Repository

10-8-1976

\title{
Animal Rights: NIH Cat Sex Study Brings Grief to New York Museum
}

Nicholas Wade

Follow this and additional works at: https://www.wellbeingintlstudiesrepository.org/hensppite

Part of the Animal Experimentation and Research Commons, Bioethics and Medical Ethics Commons, and the Laboratory and Basic Science Research Commons

\section{Recommended Citation}

Wade, N. (1976, October 8). Animal rights: NIH cat sex study brings grief to New York museum. Science, 194(4261): 162-167.

This material is brought to you for free and open access by WellBeing International. It has been accepted for inclusion by an authorized administrator of the WBI Studies Repository. For more information, please contact wbisr-info@wellbeingintl.org.

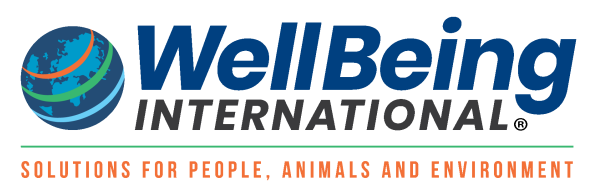




\title{
Animal Rights: NIH Cat Sex Study Brings Grief to New York Museum
}

\author{
Nicholas Wade
}

A public relations disaster has settled like a poisonous fog over the American Museum of Natural History in New York and seems to grow thicker with every attempt to dispel it.

The cause of the disaster is a study of cats performed by two of the museum's investigators. For 15 years they have been analyzing the animals' sexual behavior by the standard physiological procedures of removing glands, nerves, or brain tissue. But news of the study came only recently to the attention of New York's many animal lovers, since when the museum has been sandbagged with just about every item in the public relations consultant's book of horrors. Almost every weekend for the last 3 months there have been picket lines or demonstrations held outside the museum's stately quarters overlooking Central Park. Newspaper coverage of the affair has ranged from the critical to the unreservedly hostile, delivered under headlines such as "Cats Are Tortured in Vicious Experiments at Famous N.Y.C. Museum" (National Enquirer), "Museum Ends Its Silence on Study of Cat Sex Lives" (New York Times), and "Congress Pays for Sex Sadism at Museum" (Our Town).

With help of this kind, the affair has swollen to national proportions. Protests at the experiment have arrived from all over the country in a growing torrent-400 letters in June, 650 in July, and about 1500 in August. Some 30 congressmen have inquired about the study in response to constituents' complaints. Representative Hamilton Fish of New York wrote to the museum to say he was "personally appalled to learn that such experiments have been going on for 15 years," and another New York Representative, Edward Koch, came up with an interesting example of the non-smear smear technique. "While I am not prepared at this moment to label the kind of experimentation as Nazi-like, it does recall the barbarities of the Nazis," he wrote in a letter to the Secretary of Health, Education, and Welfare.

The affair has brought the museum bomb threats and threats to kill or maim the staff involved in the study. Though these have not materialized, a more tangible threat is the vigorous campaign by the animal rights groups to reach the museum's sources of the support. Picket lines have been thrown up to persuade the public not to enter, and letters written to the museum's members, donors, and trustees. Little support has been lost so far-some 60 people have canceled their membership and one benefactress has cut the museum out of her will-but the long-term effect on the museum's image may prove more serious. "Clearly our reputation is being damaged," says the museum director Thomas $D$. Nicholson.

The museum's plight carries a warning for other institutions whose experiments with animals are susceptible to being made the focus of public passions. The animal rights groups are particularly well informed about the cat study because, through the Freedom of Information Act, they obtained all the investigator's grant applications from the National Institutes of Health. Second, the issue of animal rights has been taken up recently by several young philosophers whose writings have injected a new intellectual vigor into the movement. The animal rights groups believe that there is a historical trend in their favor which goes from minorities' rights, to women's rights, to animal rights. The attack on the American Museum of Natural History is just the first shot in what they hope will be a broader campaign. 
The museum, however, was picked on first because it is a particularly vulnerable target. Most people are surprised to learn that any experiments at all are carried on there. That the study is on a species of household pet, and concerns sexual behavior, both topics which most people have little difficulty in relating to, has also made the study harder to explain and defend to the public.

The chief architect of the museum's discomfiture is Henry Spira, a New York high school teacher and free-lance journalist. Spira noticed an abstract of the cat study in a list of animal experiments disapproved of by United Action for Animals. His action in obtaining the grant applications under the Freedom of Information Act was crucial because it brought to light a wealth of detail about the study that would riot otherwise have been available.

The chief investigator for the project is Lester R. Aronson, the curator of the museum's department of animal behavior and one of the early pioneers in developing the quantitative study of sexual behavior. With his assistant, Madeline L. Cooper, he has been probing the sexual behavior of domestic cats for almost two decades, mostly with the support of the National Institute of Child Health and Human Development (NICHD). NIH funding of the project has totaled $\$ 412,143$ over the last 15 years.

The general method of the study has been to observe the behavioral changes that ensue from depriving the cats of various kinds of sensation or brain function. The grant applications describe experiments that call for such operations as destruction of the cochlea, section of the optic nerve, ablation of the olfactory bulb, lesioning of the amygdala, deafferentation of the penis, and castration.

In plainer language, of course, this means that the experimenters planned to deafen the cats, blind them, destroy their sense of smell, remove parts of the brain, sever the nerves in the penis, and cut off their testicles. (The experiment requiring the cats to be blinded and deafened were in fact never carried out). To those not inured to the practices of experimental psychology, it sounds like no picnic.

Spira is not an all-the-way antivivisectionist, like many in the animal rights movement, but he believes that for the purposes of many experiment, the scientist can use alternative, to live animals, and that the killing of live animals in school room demonstration, is brutalizing and unnecessary. When he received Aronson's grant applications from the NIH in August last year, he saw the cat study as an ideal vehicle for advancing the cause. He showed the documents to the New York Times, which was not interested in the story at that stage, and then to various animal rights groups.

"There's a room you will never enter at the American Museum of Natural History. It's filled with suffering animals--and your tax money is paying for it. Demand an end to the experimentation and animal suffering."

So began a widely circulated leaflet put out by the Society for Animal Rights. Friends of Animals took out a full page ad in the New York Post to say:

Believe it or not, they're torturing cats and kittens at the American Museum of Natural History ...

Why? For what purpose?

For crude, absurd sex experiments. Paid for with our tax dollars. So that researchers can study the sexual performance of crippled cats.

And toward what goal?

There is none. It is simply "experimentation" for its own sake. 
Spira himseff wrote a series of articles on the subject for Our Town, a weekly Manhattan newspaper, arguing that Aronson's experiments were "crude and routine" and unlikely to produce any new knowledge. "It's not a question of giant medical breakthroughs; nor balancing whether animals should suffer or people; but a way of getting government grants in exchange for animals' agony and blood. Congress should be forced to choose between the greed of the vivisectors and the real needs of our society," Spira stated.

The animal rights groups were thus able to get their side of the case well publicized in the media. In fact, to a surprising extent, they are the media. The president of Friends of Animals is Cleveland Amory, a columnist and broadcaster. Head of the Vivisection Investigation League is Pegeen Fitzgerald, who has a daily radio show on WOR radio. "There is not a day when we are not talking about animal matters," she says. Fitzgerald, Spira, and Ed Kayatt, editor of Our Town, have formed a steering committee whose aim is to have the museum close down not only Aronson's experiment but the whole department of animal behavior.

Given the nature of the experiment, and its critics' entrenchment in the media, the museum had clearly been dealt a poor hand. But in retrospect at least, it seems to have played diffidently even the cards it had. At first authorities refused to let Aronson speak to the press or allow reporters to visit his laboratory. When the museum finally yielded and reporters found only a roomful of frolicsome felines instead of the soundproof torture chamber they had been lead to expect, their suspicion was so rampant that even the New York Times implied the place had been cleaned up the night before.

Asked by the NIH for a review of its animal welfare procedures, the museum authorities, instead of getting an independent committee to write them a clean bill of health, turned to a group which consisted only of people with ties to the museum, and which included Aronson, Cooper, and the consulting veterinarian to the project.

The museum's few public statements have been couched in general terms, in contrast to the detail-laden accusations of the animal rights groups, and it has also shifted its main defense of the project from arguing that all basic research is important to contending that the cat study "relates closely to human problems."

The animal rights groups' case rests chiefly on three contentions, that the cats are inhumanely treated quite apart from the needs of the experiment, that the experimental manipulations are cruel and ethically unacceptable, and that the experiment itself is unlikely to lead to any significant new knowledge.

The belief that the cats have been kept inhumanely stems from statements in Aronson's grant applications, such as the reference to a "transfer cage" for handling violent animals. Aronson explains he asked for the cage because he planned to make a certain brain lesion which is said in the literature to make animals aggressive. (In fact, like the proposals to blind and deafen cats, the experiment was never performed.)

As for the famous soundproof room, the museum in a public statement denies that it exists. It does exist-the grant applications describe a "sound retarded" testing room—but its purpose is to insulate the experiment from outside noises rather than to muffle the screams of tortured cats.

Aronson's cats have every appearance of being well treated, it is in the interests of the experiment to keep them as well as possible, and the numerous outside inspections of the laboratory have never found any evidence of the cats being poorly housed, fed, or cared for. This charge may confidently be said to be groundless. 
Whether the experiments themselves can be said to be cruel is a judgment that may be influenced by the perceived worth of the experiment, the greater its value the more justifiable being the harm done to the cat. While none of the manipulations (proposed or actually done) would have done the cats any good, operations such as castration are not unique to Aronson's lab but are the fate of many a household pet. The allegations by the animal rights groups that the experimenters took a sadistic pleasure in the experiments is an obvious absurdity. Aronson says that surgery was conducted under anesthesia, as is customary, and the animal rights groups have offered no evidence for doubting the statement. On the other hand, the public outcry about the experiments stems from the difference between what the experimental psychologist and the ordinary person would instinctively regard as cruel.

The third charge, that the experiments are useless, raises an issue of some complexity. The project seems to have started out as purely basic research. Only in the most recent application, that of 1974 , is there reference to specific clinical problems, the control of oversexuality and undersexuality. Since the clinical relevance of the study has come to be asserted only recently. perhaps reflecting the changing public attitudes toward the funding of science, it is probably as basic research that the cat study should be judged.

As evidence of its merit the museum and the NICHD point to the fact that it has been reviewed and recommended for support four times by the NIH's peer review system. Peer review committees are composed of the nation's leading experts in the field and it is difficult to second-guess their judgment. But one kind of second opinion is offered by the Science Citation Index, which annually lists for each article the times it has been cited in the scientific literature that year. Of the 21 articles that Aronson and his colleagues have published on the cat study since 1962, 14 have never been cited in the scientific literature between 1965, when the Science Citation Index starts, and March 1976. Because of the short citation half-life of scientific papers, it is unlikely that they ever will be cited. The seven other papers have an average 5.6 citations each over the same 11 -year period.

If a paper is never cited-as indeed is the fate of about half the scientific articles published-it is hard to make the case that it has contributed in any important respect to the advance of knowledge. On the other hand it is easy to argue the importance, for example, of a classic paper on monkeys which Aronson published in 1934 but which is still regularly cited. (Most of Aronson's work has been on fish, the cat study taking only a third of his time.)

Yet the project may have received fewer citations than others of comparable merit simply because few people conduct this kind of work on cats. "Aronson is in a single investigator field," says William A. Sadler, the NICHD project officer and an articulate defender of the study. According to Aronson, "Most of the research on reproduction is in rats and the rat people are very parochial in that they only read the rat literature and only cite rat studies, so very frequently our papers are not cited."

Whatever the citation rate of the cat study, the animal rights groups' campaign has been a harsh ordeal for Aronson and Cooper. Aronson, who is aged 66 and has been planning in any case to retire soon, is an established and productive scientist whose work, in the aspects for which it is being assailed, differs in no way from the research carried on by a great many other investigators.

Even the animal rights groups concede this point in their own way. "Aronson is no different from thousands of others," says Eleanor Seiling, the indefatigable force behind United Action for Animals. Seiling, in whose bulletin the Aronson study was first brought to the animal groups' attention, believes that the "vendetta" against Aronson is futile. "I want something done not just about the museum, I want to change the system," she says. 
Whether the animal rights groups have the power to change the system is open to doubt. Most of them are essentially one-person organizations, each bitterly jealous of the others. Even the crowd-drawing campaign against the museum has been marked by a feud between the Society for Animal Rights and a loose coalition of 11 other groups. The Society for Animal Rights held its meetings on different dates and has now ceased to demonstrate altogether because more aggressively minded groups prevented its demonstrations from being orderly. About the only unifying factor among the various groups is their dislike for Representative Koch, who has introduced legislation in Congress to set up a commission on the humane treatment of animals. The animal groups accuse him of using the museum affair to gain publicity for himself. They make similar accusations of each other. For example the Society for Animal Rights, whose expenses last year exceeded its revenues by $\$ 136,000$, has been criticized for attacking the museum and soliciting donations in the same advertisement.

Another impediment to political influence, besides their lack of unity, is the extreme nature of the positions taken by the various groups. Between the out-and-out antivivisection position of the Vivisection Investigation League and the viewpoint of United Action for Animals that virtually all experimental animals can be replaced by nonliving alternatives, there is little chance for a more moderate and generally persuasive doctrine to emerge.

On the other hand, the animal rights groups believe that the tide of the times is moving in their favor. They believe that the same sense of justice and humanity which animated the sentiment for minorities' rights and then for women's rights will eventually be asserted on behalf of animals, both those used in laboratories and those killed for meat." People are widening the sphere of their consciousness," says Nancy Stassinopoulos of the Society for Animal Rights; "They are better informed and better educated, and they are perceiving man's place in nature and his relationship toward animals in a different light."

The issue of animal rights has recently been taken up by people from outside the mainstream animal lovers, such as philosophers. For example Robert Nozick of Harvard, whose Anarchy, State and Utopia has received rave reviews from his colleagues, devotes a section of the book to animal rights. While Nozick does not specifically address the use of animals in experiments, he considers that animals should count for something, and for enough at least that they should not even be eaten. "The extra benefits Americans today gain from eating animals do not justify doing it," Nozick concludes.

Another philosopher to take up the issue is Peter Singer of Melbourne University, whose book Animal Liberation has become the new testament of the animal rights movement. "It has helped create a whole new seriousness about animal welfare," says Spira, who attended a course Singer gave at New York University in 1974.

Singer's thesis is that we must "extend the basic principle of equality of consideration to members of other species. I ask you to recognize," he says in the preface to this book, "that your attitudes to members of other species are a form of prejudice no less objectionable than prejudice about a person's race or sex." Singer believes that such prejudice is exhibited by researchers who give no weight at all to the sufferings of the animals used in their experiments, and in proof he cites many experiments in which severe pain is caused for arguably trivial results. Singer marshals his arguments well and stops some way short of an out-and-out antivivisectionist position (methods involving animals, he says, "should be replaced as soon as possible" by alternative methods).

Researchers use a surprisingly large number of animals-some 63 million a year in the United States alone, according to one estimate, a figure which includes 85,000 primates, 500,000 dogs, 200,000 cats, and 45 million rodents. When the right nerve is touched, the issue can arouse strong public passions, as the Aronson study has shown. A similar case in 1973, involving the Department of Defense's use of 
beagles, brought the House Armed Services Committee more mail than it had received on any event since Truman sacked General MacArthur. Does the public appeal of the animal rights issue depend only on misplaced sentiment, or is there an argument somewhere there to be answered?

\section{Sadism Frowned On}

While most researchers doubtless respect the interests of their animals as much as possible, the codes of practice governing animal experimentation do not concede that animals have any rights whatever that should weigh against the purposes of the experimenter. The statements of principles issued by the American Psychological Association (APA) and the National Society for Medical Research simply require that animals be well kept (which is generally in the researcher's own interest). The principles implicitly embody an absolute freedom by the researcher to use animals however he will. In fact the greatest moral burden laid on the experimenter by the APA is not to be positively sadistic: "Research procedures subjecting animals to discomfort shall be conducted only when such discomfort is required, and is justified by the objectives of the research," says the code which the APA's council of representatives found worth approving.

Just as the researcher is not required or formally encouraged to make animals count for anything in the design of his experiment, so the peer review system makes no formal attempt to balance the worth of an experiment against the interests of the animals whose lives it would take. Study sections are instructed to consider proposals on their scientific merit alone. Thus an experiment of minor merit requiring a hecatomb of animals might in theory receive a favorable mark. In practice, study sections do tum down experiments that surpass a certain combination of harshness and triviality. Keith Murray, executive secretary of the $\mathrm{NIH}$ 's experimental psychology study section, says that there have been occasional instances when an application was turned down because of unnecessary cruelty. He cites as an example a proposal, which the investigator submitted three or four times to blind infant monkeys in order to study how well their mothers looked after them.

A practical test of one's treatment of others is reciprocity. What if the Andromedans arrived (a question posed in essence by Nozick), demonstrated that they were as intellectually superior to us as we are to animals, and said that they regretted that they would have to use a few million humans in a basic research project of quite considerable merit? The APA's code of principles would not be much of a fence to hide behind.

"Surely one day," Singer observes in Animal Liberation, "our children's children, reading about what was done in laboratories in the 20th century, will feel the same sense of horror and incredulity at what otherwise civilized people can do that we now feel when we read about the atrocities of the Roman gladiatorial arenas or the 18th-century slave trade." The projection may sound far fetched, yet history teaches that only fashion in clothes changes faster than fashions in ethics.

\section{Recommended Citaiton:}

Wade, N. (1976, October 8). Animal rights: NIH cat sex study brings grief to New York museum. Science, 194(4261): 162-167. 